$\begin{array}{ll} & \text { Etnográfica } \\ \text { etnográfica } & \text { Revista do Centro em Rede de Investigação em }\end{array}$

Antropologia

vol. $19(2) \mid 2015$

Vol. $19(2)$

\title{
Negotiating desirability and material resources: changing expectations on men in post-Soviet
}

\section{Havana}

Negociação da desejabilidade e recursos materiais: mudanças das expetativas acerca dos homens na Havana pós-soviética

\section{Heidi Härkönen}

\section{(2) OpenEdition}

\section{Journals}

Electronic version

URL: https://journals.openedition.org/etnografica/4032

DOI: 10.4000/etnografica.4032

ISSN: 2182-2891

\section{Publisher}

Centro em Rede de Investigação em Antropologia

\section{Printed version}

Date of publication: 1 June 2015

Number of pages: $367-388$

ISSN: 0873-6561

\section{Electronic reference}

Heidi Härkönen, "Negotiating desirability and material resources: changing expectations on men in post-Soviet Havana", Etnográfica [Online], vol. 19 (2) | 2015, Online since 22 June 2015, connection on 10 February 2022. URL: http://journals.openedition.org/etnografica/4032 ; DOI: https://doi.org/ 10.4000/etnografica.4032

\section{(c) (1) \&}

Etnográfica is licensed under a Creative Commons Attribution-NonCommercial 4.0 International License. 


\section{Negotiating desirability and material resources: changing expectations on men in post-Soviet Havana}

\section{Heidi Härkönen}

In post-Soviet Havana, material resources emerge as a factor in terms of which women assess a man's desirability as a potential partner. These tendencies in current gender relations relate to the larger transformations in Cuba's political and economic context. The fall of Eastern European and Soviet state socialisms seriously diminished the Cuban state's ability to provide social services. Remittances generated through transnational kin ties and recent liberalistic changes in labour politics intensify the disparities of wealth. Moreover, Cuba's dependence on tourism as a source of national income has brought about changes to the possibilities for social mobility available through the promises of migration and affluence that relationships with foreigners can offer. This article focuses on the gendered consequences of these large-scale transformations, experienced as the increasing intertwining of material resources and desirability, especially when it comes to men's attractiveness. Coping with increasing demands from women, men draw on local notions of masculinity that include elements both of machismo and responsible manhood. Men thereby at times comply and at times resist women's expectations on them.

KEYWORDS: Cuba, masculinity, gender, monetisation, love, sexuality.

Negociação da desejabilidade e recursos materiais: mudanças das expetativas acerca dos homens na Havana pós-soviética - No contexto pós-soviético em Havana, os recursos materiais são critério para a mulher avaliar a desejabilidade de um homem como potencial parceiro. Tais práticas nas relações de género estão ligadas às transformações políticas e económicas mais vastas. A queda do socialismo soviético e no Leste da Europa diminuiu drasticamente a capacidade do Estado cubano para prestar serviços sociais. As remessas geradas através de redes transnacionais de parentesco e a liberalização recente das políticas laborais intensificaram as disparidades na distribuição da riqueza. A dependência do turismo como fonte de rendimento nacional gerou novas possibilidades de mobilidade social através do relacionamento com estrangeiros, pela promessa de migração e prosperidade. $\mathrm{O}$ artigo centra-se nas consequências destas transformações em termos de género, concretizadas numa maior interligação entre os recursos materiais e o que torna os homens desejáveis. Em resposta à exigência crescente das mulheres, os homens ativam noções locais de masculinidade que incluem elementos de machismo e responsabilidade masculina, por vezes correspondendo e outras vezes resistindo às expetativas das mulheres que sobre eles recaem.

PALAVRAS-CHAVE: Cuba, masculinidade, género, monetarização, amor, sexualidade.

HÄRKÖNEN, Heidi (hkharkonen@gmail.com) - Independent researcher, Helsinki, Finland. 


\section{INTRODUCTION}

One day my Cuban friend Yanay found herself a new man whom she considered to be a real catch:

"- He makes 1200 [Cuban] pesos [about 52 USD] in a day because [at his work] they divide the tip and share the money between them. He is not good-looking, a very skinny [...] guy. And he had a perfume Issi Miya...

— Issey Miyake?, I suggested.

- Yes, the one that costs 30 dollars [CUC] and I put it on and it lasted on me all the way until the next day! And he bought lots of beer, we went to a disco in 10 de Octubre [a neighbourhood in Havana] and it was packed with people, expensive beer that costs 1,25 [CUC] and [Heineken] of 1.50 [CUC]." 1

Money has become increasingly linked with attraction in contemporary Havana. ${ }^{2}$ Women in particular pay considerable attention to a man's material resources in their views about a desirable partner. Women expect men to have the money to court them, to take them out to restaurants and discos, to indulge them with little gifts and to provide them regularly with funds to tend their personal needs. While money is not the only factor linked to a man's attractiveness, it does play a significant role in a man's ability to create relationships with women. No one wants to be with a muerto-de-hambre (someone who is starving to death). ${ }^{3}$

Cuban gender and family relations are in general characterised by very similar tendencies to those described by many of the classical works (e.g. Clarke 1974 [1957]; Smith 1988, 1996) on Caribbean matrifocal kinship: the bond between mothers and children is exceptionally strong, legal marriages are rare and men are seen as relatively marginal to family relations in their role as

I Two different currencies are in circulation in Cuba: the Cuban peso (CUP, moneda nacional), and the convertible peso (CUC), which is close in value to the USD. One CUC/USD equals 23-24 CUP. The average monthly salary is currently about 20 USD (Anonymous 2008). At the time, the normal price for a beer was 1 CUC.

2 This article is based on research material collected in Havana through ethnographic fieldwork amongst relatively low-income, racially mixed (ranging from black to all shades of brown to white) Cubans in 2007-2008. My research participants can be characterised in many ways as "ordinary people." Unlike the research subjects of many contemporary studies on Cuba, my respondents did not engage in sex work, they did not make a living on tourism (or jineterismo), they were not marginalised politically or sexually, nor were they in a specifically advantaged position either. All the names of the research subjects have been changed and I have blurred some biographical details in order to better preserve their anonymity. I am using local racial categorisations and all translations from Spanish to English are my own.

3 This is a popular Cuban expression used to refer to poverty. 
fathers. ${ }^{4}$ Moreover, gender relations can often be fragile and change rapidly. It is common that some of such relationships result in children, who are deeply cherished by all Cubans. The attainment of parenthood is a fundamental factor in gaining full adulthood for both men and women.

Although money played a role in social relations already before the 1990s (see Rosendahl 1997: 61-62), the current importance of money to gender relations seems to be something new that is closely related to wider transformations that have taken place in Cuban society in the post-Soviet period. The severe economic crisis that Cuba encountered in the 1990s due to the collapse of the Soviet Union forced the state to make several concessions to the socialist ideology, such as allowing the formation of small private enterprises, legalising the use of double currency and opening the country to international tourism (e.g. Eckstein 1994: 88-127; Azicri 2000). The 1990s also witnessed the increasing monetisation of Cuban society and since this "dollarization" (Eckstein 1994: 125), most material items have become available to Cubans only through money - whether in the official state shops or in the informal economy - as opposed to the previous possibility to receive them as state contributions. This has emphasised the significance of personal social relations in providing Cubans with the needed material contributions in the context of day-to-day life.

Many scholars argue these changes to be connected to social changes such as increased differences of wealth (e.g. Azicri 2000: 71-99; Roland 2006; Porter 2008; Weinreb 2008; Cabezas 2009; Hamilton 2012: 75-80, $113-116$, 214-231), greater significance of markers of wealth and privilege (Holbraad 2004: 649-65 1; Porter 2008; Allen 201 1: 37-38; Lundgren 201 1), intensified desires of consumption (Holbraad 2004; Porter 2008; Allen 201 1), increased significance of racialised differences (de la Fuente 2001a, 200lb; Roland 2006, 2011 ; Weinreb 2008; Cabezas 2009; Fernandez 2010: 7, 47-48, 128-130; Allen 2011; Hamilton 2012: 47, 75-80, 113-116, 214-231), as well as the new importance of the body as the site where such privileges are marked and expressed (Lundgren 2011).

Several of these changes in social relations since the 1990s conform to Susan Gal and Gail Kligman's (2000a, 2000b) observations on the transformations

4 There are also certain differences between these descriptions on Caribbean matrifocality that draw on the Anglophone Caribbean and contemporary Cuban gender and kinship relations. In the Anglophone Caribbean, even though legal marriages are rare especially among low-income Afro-Caribbean people, legal marriage still holds value as an important status symbol (cf. Clarke 1974 [1957]; Smith 1988, 1996; Barrow 1996; Freeman 2000). Amongst my Cuban interlocutors, legal marriage was not valued in such a way. Nevertheless, my ethnographic material points to the significant relevance of matrifocality amongst my research participants (Härkönen 2014); Jean Stubbs (1997), Helen Safa (2005), Elise Andaya (2007: 219-220) and Anna Pertierra (2008), all see contemporary Cuban kinship relations as characterised by bonds very similar to notions of Caribbean matrifocality. There is little ethnographic information on Cuban gender and kinship relations apart from these works so it is not possible to provide a detailed historical account on the subject (see however Martinez-Alier 1974: 124-130). 
that have taken place in Eastern Europe during the post-socialist period. They connect such large-scale social, political and economic transformations to increasing class differentiation, a decline in state subsidies and changes in the possibilities for social mobility. Gal and Kligman emphasise the gendered nature of such large-scale transformations.

In a similar vein, Jennifer Cole and Lynn M. Thomas (2009: 6) argue that social and economic transformations may bring changes to grassroots intimate relations of love. Monetisation in particular has been noted to bring transformations to gender relations in different parts of the world. Even though economic changes are experienced and enacted drawing on long-term notions of gender and kinship, they still transform the logic of intimate relationships in complex ways (e.g. Wardlow 2006; Hirsch and Wardlow 2006; Cole and Thomas 2009).

I suggest that the transformative processes that have taken place in Cuba in the post-Soviet period and the types of changes that they may have brought to social relations should be examined as gendered. My ethnography shows that such processes as the increased monetisation of exchanges or the new significance of consumption take shape as gendered and are experienced through local conceptualisations of gender difference - simultaneously as they also transform social relations. While these tendencies represent changes in comparison to social relations in the Soviet-era, they at times seem to reproduce situations reminiscent of the colonial era in terms of their gendered, racial and economic implications, when beautiful mulatas partner with men who are visibly lighter-skinned and wealthier than them. In Cuba (Martinez-Alier 1974), as elsewhere in the Caribbean (e.g. Newman 2010), since the colonial era, sexual relations have offered non-white women in particular a way to seek socioeconomic ascendance by maintaining relationships with wealthier or "racially" higher-status partners.

In the increasingly monetised post-Soviet Cuba, this situation has the power to produce gendered marginalisations. Maurice Godelier (1999: 2-3) argues that in a monetised economy, income is crucial in maintaining a social life, as money is needed for all types of activities from the most everyday to the more ritualised. Thereby, when undergoing liberalist re-structuring, states also indispensably exclude certain groups of people from society as not everyone has the means to access a sufficient income.

While the changes that continue to take place in Cuba's economic, political, and social climate affect the lives of both men and women, this article examines the ways in which these larger transformations influence the lives of men. Despite the current interest in masculinity studies, men are often relatively neglected in studies on Caribbean kinship, sexuality, and gender relations (see also Hamilton 2012: 102). Through an exploration of how men negotiate their relationships and women's increasing expectations by drawing on distinct local notions of masculinity in post-Soviet Havana, this article complements the 
discussion on diverse masculinities and the ethnographic study of Caribbean gender and sexual relations.

\section{MEN'S ATTRACTIVENESS AND MATERIAL RESOURCES}

Drawing on Marilyn Strathern's (1988: ix-x) insight that gender can only be understood as a difference, Matthew C. Gutmann (1997: 843) argues that in studying masculinity, we should pay attention to the accounts that women give on men, because "women's involvement [is] central and invaluable to any ethnography of men." He states that masculinities can only be understood in relation to meanings and practices connected to women. ${ }^{5}$ This is why it is useful to pay attention to the hopes and expectations that women place on men, as these play their own part in shaping gendered relationship dynamics and consequently men's experiences of love and sexuality.

Yanay's statement is exemplary of the views that my female respondents had about desirable partners: a man's attractiveness is deeply intertwined with his material possessions. No matter how good-looking my female respondents would find a man, he was out of the question if he was perceived by them as being completely without money. While most women were not as successful as Yanay in hooking up with wealthy men, many, however, had partners who provided them with regular contributions of small sums of money and material gifts (such as food, beer, and clothes). A good man has the ability and desire to pay for diverse things and outings and he frequently provides his partner with food and commodities.

Consumption is thereby closely connected to a man's possibilities to create relationships with women. ${ }^{6}$ Both men and women told me that a Cuban woman does not take any money with her when she goes out on a date with a man. While women tend to spend their money most importantly on their children, other kin, and (more rarely) on themselves, men's money goes significantly to the women with whom they are, or wish to be, romantically involved. In the context of many Cubans' low level of income and the country's high prices, such gendered courting practices place a big strain on a man's income: a night out in a disco may take up an entire month's wage, even more.

When first meeting up with a new man, my female respondents assessed his material resources by paying close attention to his clothes and to the way

5 Carrie Hamilton (2012: 112) makes a similar point in her discussion on Cuban sexual history: "Just as women's narratives of love, marriage, and missing men provide clues to both dominant values of masculinity and the diversity of men's expectations and experiences, so, too, male narrators' stories about their female partners point to ways of thinking about changing Cuban femininities."

6 See also Porter (2008: 144), who in discussing a female respondent's ideas about relaxing, points out that they all involve acts of consumption. 
in which he used money. Drinking foreign beer, wearing Nike trainers and gold chains, as well as sharing his money generously are all valued as signs of desirable qualities in a man. A man with money is expected to share it and use it on providing for women and male friends (see also Rosendahl 1997: 61-62; Holbraad 2004: 649-651). These are examples of the extension of global notions of consumption to Cuba in particular since the 1990s, showing how wealth must be worn and consumed (Allen 2011: 37-38; see also Porter 2008: 142-143), the new importance of the body as a site for expressing privileges (Lundgren 2011: 121-125), and the intertwining of such practices with conceptualisations of masculinity.

Mark Hunter (2009: 146-152) describes similar views on desirable masculinity in South Africa, where in the midst of economic difficulties since the 1980s the ability to consume and shower girlfriends with gifts became the qualities that women found the most attractive in men. Cole and Thomas (2009: 22) connect this with a shift from an economy of production towards an economy of consumption. While there are great differences between the Cuban context and the South African situation described by Hunter, his material is similar to the ways in which my female respondents emphasised a man's ability to spend as evidence of his desirability as a partner. While Cuba can hardly be seen to represent an economy of consumption as such (compared to many places, there is little to consume), this does suggest that Cubans' intensified desires for consumption (Porter 2008) intertwine importantly with gendered expectations in love and sexual relations, at the same time exemplifying the continuing importance of generosity to Cuban notions of masculinity (see Rosendahl 1997: 61-62). In a transformed situation, more long-term conceptualisations of masculinity are reworked by women to place new demands on men (Hunter 2009: 148).

Women may sometimes be very straightforward in their expectations of men's material contributions, making claims that men struggle to meet. Yet men often find it hard to deny women's requests of spending. For a man to deny his money to his partner raises suspicions of stinginess, a characterisation that most men would prefer to avoid. Moreover, being very tight with his money might also question his personal ability to make a living, leading at the worst case to a description of him as a muerto-de-hambre - another feature that all my research participants found highly despicable. Finding ways to make money, knowing how to survive and resolver (resolve problems), are all qualities that connect with notions of desirable masculinity. Such resourcefulness intertwines complexly with a man's material assets: good skills in resolving problems become visible in a man's access to diverse possessions, showing that he is able to get hold of money and commodities and is willing to share his resources with his partner. At the same time, money in itself matters. When Xiomara's sister changed her young, handsome and resourceful boyfriend for 
a significantly older and wealthier, but bad-mannered man, Xiomara stated: "Yes, but Yonkiel [the sister's ex-boyfriend] didn't have money, this one has money!"

Possessing other forms of material resources also gives a man advantage in his relationships: having access to a car or decent housing conditions increases his attractiveness to women. The lack of adequate housing has been a constant problem in Havana throughout the revolution (and even before; see Butterworth 1980; Hamilton 2012: 218-229) and the city continues to be full of deteriorating, overcrowded flats. Carrie Hamilton notes that since pre-revolutionary times, heterosexual relationships have provided women with a way to acquire housing (2012: 220, 224-226, 229). This increases the importance that having access to (decent) housing has to a man's ability to attract partners. While Anna Pertierra (2008) argues that during the post-Soviet era the house has increased in symbolic value for women, I suggest that housing also holds central value to men. As the idea of family and home/house (casa) often merge (Pertierra 2008: 753-754), housing (as the family home) becomes connected to notions of security, stability and kinship continuity. Owning an apartment places a man in the position of a well-established man mature enough to start a family. Although in practice Havana's on-going housing crisis often forces Cubans to negotiate this ideal, providing housing for his partner forms part of local conceptualisations of responsible masculinity.

Material contributions from men to women connect with the idea that the man is supposed to be the breadwinner who brings resources to the household. While the state has tried to discourage such gendered practices by promoting women's extensive participation in the workforce and even though the huge majority of women do work, some type of a cultural ideal of a man who provides for his family lives in Cuba - despite the fact that in some households the majority of income may in practice be provided by women. ${ }^{7}$ The Caribbean has a long history of non-white, lower-income women working outside the home, although this has been connected more profoundly with the English-speaking Caribbean (see Wong 1996; Freeman 2001). Virtually all my female interlocutors were engaged in some type of an employment that generated for them

7 For the official employment statistics, see data from Oficina Nacional de Estadísticas de Cuba (ONEC 2010). At the same time, women who are not included in such official statistics are often also engaged in various forms of income-generating work (see Pertierra 2008). Safa (2005) and Pertierra (2008) both argue that the post-Soviet era has seen an increase in the position of women as the primary providers for their households. Stubbs (1997: 255), however, points out that since the 1990s, Cuban women "appear to be retreating back into a family survival role." Moreover, amongst my research subjects, a considerable part of the money and goods that women had access to actually came to them from their partners or admirers. This highlights the importance of paying attention to day-to-day gendered exchanges. In the case of Pertierra's material, such dissimilarities may of course also reflect differences between Havana and Santiago. 
some income of their own. Yet, at the same time, if a woman is romantically involved with a man, there is a strong expectation on him to provide her with some money and food.

Although there are men who have relationships with women in such arrangements that money flows from the woman to the man, this is, however, an inversion of how things "should" go. Some of my male respondents felt uncomfortable with such gendered exchanges. While for women, to receive money and material support from their partner confirms their femininity, for men such behaviour risks questioning their "proper" masculinity.

If a man started to show signs of stinginess, my female research participants were quick to lose interest. In a relationship, a man's inability or unwillingness to give money and material contributions to his partner is closely connected to many women's desire to end the relationship. A man who neglects his material contributions to his partner, quickly risks losing her since women interpret this as a lack of interest from the man's part - concluding that he no longer desires to continue the relationship - or as an indication that he is sharing his material resources with another woman. ${ }^{8}$

Notions of responsible masculinity thereby intertwine importantly with a man's material possessions and his ability to provide economically for his partner and children. While this gendered connection between material resources and responsibility is significant to a man's social relations throughout his life course, it becomes particularly highlighted in the context of fatherhood.

\section{FATHERHOOD AND MATERIAL WEALTH}

Parenthood is fundamentally tied to notions of mature, gendered adulthood in Cuba. ${ }^{9}$ Having children is seen as a crucial part of the normal life cycle for both men and women. This way, fatherhood is closely connected to notions of masculinity.

Pregnancy, birth and childcare are considered very strongly as women's issues. Deciding whether to have a child is seen as entirely a woman's choice. It is up to a man to convince a woman of his suitability as a father.

Material conditions play a particularly important role in women's views and decisions about pregnancy. When reflecting on a particular man's suitability to fatherhood, women often assess a man's material resources and likelihood to provide for his child. Having access to a car, housing, or having a job in the - by Cuban standards lucrative - tourist industry, are all issues that make

8 Both male and female infidelity were rather common occurrences amongst my research participants, although male infidelity was much more culturally permitted.

9 For similar notions from other parts of the Caribbean, see Clarke (1974 [1957]: 96); Barrow (1996: 397); Gussler (1996 [1980]: 129). 
a man desirable as a potential father. Even though my respondents paid some attention to a man's character in the sense that they did not want to have children with a "bad" man who "doesn't care about" his children or who "hits you," considerations over a man's possessions tended to weigh more heavily than other concerns.

Women often say that they want the father of their child to be "responsible," but a man's responsibility is largely tied to his material contributions to his partner and child. A responsible man is one who provides for his family. Since love is thought to be unreliable and relationships may break suddenly, wealthier men are seen as more likely to continue providing for the child even if the relationship with the mother ends. Thus, while love and sexual relations constantly bear the risk of turning sour, quantity in material resources is seen as creating a form of security. A man with plenty of possessions is seen as a more reliable partner than someone with fewer assets, who may stop providing for his children from a previous partner when he finds a new love. This further highlights the importance of material resources to a man's possibilities of embracing responsible masculinity.

The notion of responsible masculinity as closely connected to material security is shared by both men and women. This is exemplified in the way men often emphasise that they want to "have the conditions" (tener las condiciones) before having a child, to be able to provide their partner and child with proper material contributions and a decent home (although in practice, such plans may often go unfulfilled).

When a woman has a child "alone," without a male partner, the problem is not seen to be in the raising of the child without the father or in the woman coping with the pregnancy on her own, but rather in how the mother will raise a child without the money supplied by the father (or another male partner). Hamilton states that families without the presence of a husband/father often experience aggravated patterns of poverty (2012: 75-80, 89, 105). While I want to point out that men's material contributions to their partners do not depend on cohabitation nor on legal marriage, it is true that mothers who receive no male contributions easily struggle with making ends meet.

While in practice not all men provide money to the mother(s) of their children, they are strongly expected to do so and frowned upon if they do not fulfil this responsibility. Both men and women emphasise that responsible fatherhood entails giving money and/or other material items to female partners and children. Since material contributions connect with responsible, caring fatherhood, I see contributions of money and other material items as a crucial form of male care in Cuba. This closely intertwines views about (ideal) fatherhood, masculinity and material contributions.

Cole and Thomas (2009: 20-21) argue that material exchanges may both reflect and produce emotionally charged relationships. In discussing gender 
relations in Madagascar, Cole (2009) describes a long-term local conceptualisation of love as simultaneously material and moral/emotional, enacted in reciprocal exchanges of goods and labour distributed across social networks. This is very similar to how I understand the role of Cuban men's material contributions to their partners and children.

In the context of contemporary relationships, money is importantly gendered; it is something that men are expected to contribute to women in a system of reciprocal exchange where women respond with nurture, sexual access and children. This does not mean that women would not desire sexual relationships with men if it were not for the money, but rather that money is an object that allows men to create relationships, both sexual and non-sexual. While women also have their own money, money is importantly the means through which a man expresses an interest towards a woman, giving her small material gifts and taking her out to eat, for drinks or dancing. It is through his material contributions to her that she assesses whether he is a responsible man and someone who can help her in life. A man's provision of material support thereby becomes evidence of his emotional commitment and responsible masculinity.

Despite the fact that women tend to emphasise rather pragmatic views of men's material resources and highlight their ability to contribute, this gendered intertwining of money, material resources and a man's desirability cannot be understood as mere economic rationality. Rather, the emphasis is on the social relationship enabled by money and material resources as objects of exchange.

Caribbean men are frequently described as marginal and absent in their fatherhood; being indifferent towards their children and emphasising rather the physical ability to impregnate a woman (e.g. Clarke 1974 [1957]: 96, 161164; Wilson 1973: 149-151; Smith 1988: 147, 1996: 83-84; Gussler 1996 [1980]: 129; Andaya 2007: 201-248; Hamilton 2012: 101-109). This connects with a strong focus on the mother-child relationship and matrilateral bonds in the kinship system. While a mother's bond to the child is seen as natural, a father needs to affirm his connection to his child through material contributions. Biogenetic conceptualisations of fatherhood/kinship are not sufficient by themselves, but relations need to be affirmed through active practices of care.

In the gendered practices of reciprocal care through which Cubans create, maintain and negotiate their social bonds, money and material contributions enable men to create and continue their relationships. Material resources become a way for men to keep gendered care flowing between themselves, women and children and emphasise their commitment to specific relationships.

Although not all men take up the opportunity to create bonds with their children by giving material help to the child's mother, I argue that such 
contributions may express a strong desire from the part of the man to be a proper, caring parent for his child. This way, men's material contributions should be seen as important in their quality of installing a social relation between the baby's mother and father and between the father and the baby. However, in Cuba's difficult economic situation, sometimes even small contributions may require considerable effort from the man's part and not all men are able to access wealth for sharing it around. This creates a situation where those without money and material resources often struggle to create relations. When material contributions come to represent a man's emotional commitment to his partner and child, access to money or other material items becomes important to a man's ability to become a parent.

\section{POST-SOVIET HAVANA AND GENDERED MONETISATION}

I connect the strong importance of money for men's ability to create and maintain relationships to the overall tendency towards monetisation that has characterised Cuban society since the country's severe economic crisis in the 1990s.

Ideally, the socialist "new man" initially envisioned by the revolution was supposed to be devoid of bourgeois vices such as materialism (see Guevara 2005 [1965]). Drawing on Engels' (2004 [1884]) views on socialist gender relations, the early revolutionary government laid its hopes on women's employment as a way to create love relations devoid of material interests, governed by the true equality of men and women. Since everybody would be equally engaged in the labour force, earning their own money, material wealth would not create dependencies between people. The aim was to create a society without inequalities; a society where socialist love relationships would be embraced by people across the earlier divisions of wealth, race, age and place of residence, leading to a full egalitarianism (see e.g. Díaz Tenorio 1993; Hamilton 2012).

The importance that women currently grant to a man's position as a material provider goes against this ideal, despite the fact that none of my female interlocutors could be comfortably described as a "housewife." Since most salaries earned from official work are insufficient for living in contemporary Havana, socialist ideals are undermined by the constant economic shortage.

Since the 1990s, the state has been seriously struggling to provide goods and services to the population, as the loss of its most important political ally and trading partner, the Soviet Union, plunged the Cuban economy into severe shortages. The state was forced to cut down many of its earlier contributions and services to the population, initially designed to provide individuals with nurture from cradle to grave, following socialist state ideals. These economic problems brought ruptures to the earlier ideals of egalitarianism, as the opening of the country to tourism, more possibilities for private business and the heightened role of remittances all played their role in increasing the 
old divides of wealth and race amongst the population (see e.g. de la Fuente 200la, 200lb; Cabezas 2009: 57, 64, 79-81; Allen 2011; Roland 201 1). As the state continues to retreat from more and more aspects of society, dayto-day existence has become increasingly monetised, since many goods and services that used to be provided by the state can now be acquired only in the cash economy. Moreover, material gifts have become an important way to cultivate relationships that guarantee an access to distinct state (and other) services (see Brotherton 2005, 2008; Andaya 2009a; Kath 2010). At the same time, most items in Cuba's new economy are extremely expensive for individuals and nearly all Cubans work second jobs in the informal economy as a way to make ends meet. While material issues have undoubtedly played a role in social relations during the Soviet era, they seem to have become particularly highlighted during the post-Soviet era as state services continue to crumble.

With the transformations in post-Soviet socialism, the dismantling of many state services has brought intensified pressure to Cubans' personal social relations to compensate for state deficits. Along with the growing differences of wealth and the increased monetisation of the economy, the significance of men's material contributions to women takes on an increased importance. While the post-Soviet period has seen an increase in the feminisation of nurturance (Andaya 2009b), there has also been an increase in the masculinisation of material care, shifting to a greater emphasis on individual men as suppliers of material security instead of the state than during the more prosperous years of Cuban socialism.

Moreover, the post-Soviet period has seen an increase in Cubans' possibilities and desires for consumption (see Porter 2008; Allen 2011). Despite the fact that shop offerings continue to be meagre and highly over-priced for average wages, consumption has emerged as site of displaying distinctions of wealth that are significant in the local context - as Yanay stated, it makes a difference whether someone drinks a local beer or a Heineken, or wears a perfume that lasts. At the same time, accustomed with the notion of socialist egalitarianism (see Verdery 1996: 28), many Cubans have a strong feeling of entitlement expressed in that everybody should be able to possess such commodities as DVD players, Nike trainers and fancy cell phones. Amy L. Porter (2008) argues that differential access to consumption fragments Cubans' ideas of citizenship and national belonging and undermines a previous revolutionary focus on needs, replacing it with an atmosphere that cultivates the creation of wants and desires and dreams of their fulfilment.

While the material deficiencies and dissatisfactions of the post-Soviet period have intensified Cubans' desires for migration, heavy state investment in the tourism industry has brought to the island plenty of foreigners - attractive in their ability to provide answers to many Cubans' longings for a better life. While both men and women may enter into relationships with tourists 
and seize the opportunities of migration and social mobility that this may offer, due to the importance of money and other material contributions especially to men's possibilities to build relationships, the threat of losing their partner to someone wealthier was felt more intensely by male respondents.

Even though material resources have played a part in women's views of a desirable partner also in the past, their significance to men's ability to attract partners seems to have gained far more prominence since the 1990s. In her account on 1980's east Cuba, Mona Rosendahl (1997: 69) states that a man's wealth was not particularly relevant to his attractiveness to women; women stressed instead the importance of finding a "good" man who takes care of them and respects them. Nevertheless, in contemporary Havana, regular contributions of money to his partner are what makes a man "good." A good man cares for his partner by giving her money and supplying her with food and commodities. This suggests that while the importance of a man's material possessions to his attractiveness to women may not be anything new as such, its significance has intensified in the post-Soviet era in the context of declining state contributions and the heightened monetisation of day-to-day life.

These changes in Cuba's economic and political climate also relate to the island's low fertility numbers. Elise Andaya (2007: 170) connects Cuba's current very low fertility rates with the country's economic difficulties, as state failures to provide women with the needed nurture combine with men's frequent indifference towards children and push women to exert responsible motherhood via abortion in a situation where contraceptives are poorly available and it is difficult to provide even for one child. Pertierra (2008: $748 \mathrm{ff}$.), on the other hand, sees the declined fertility in the post-Soviet era as connected to women's desire to wait until they are able to provide economically for the children they intend to have. In this context, responsible motherhood may also be practiced through trying to secure a child as much material resources as possible by choosing a wealthy father.

Since women's personal kin and sexual relations are of primary significance in coping with the state's material deficiencies, wealthier men become more desirable as partners and fathers. This way the change that seems to be occurring in Cuban fertility, as women have fewer children than before, may also have the gendered consequence of leaving some men childless.

Due to the central role traditionally played by forms of redistribution in creating socialist state legitimacy (Verdery 1996: 23, 61-69), such practices may undermine the overall political legitimacy of the state as people come to depend more and more on their personal relations in providing them with distinct goods and services instead of the state. Nevertheless, my material suggests that instead of being expressed as a direct critique towards the state, often such deficiencies in state services just make women expect more contributions from the men in their lives. 


\section{HOW DO MEN NEGOTIATE WOMEN'S EXPECTATIONS?}

All of these state-level transformations are connected to the types of desires and expectations that Cubans set on each other. For many of my male respondents, women's expectations of money, gifts and consumption were hard to fulfil. They used different ways in coping with the transformations that the post-Soviet period has brought to their lives and negotiated women's expectations how they best could, drawing on distinct cultural notions of masculinity at different moments.

In his efforts to court Sulema, a beautiful mulata in her mid-thirties, Armando, a 30-year-old black man drew on ideas of responsible masculinity. Working as a chef in a five star hotel, he brought Sulema food from the hotel kitchen almost daily. He also gave her small sums of money several times per week and took her out to discos and bars. Sulema was pleased with Armando, stating that he was "very good" (muy bueno) - a good man - and Armando had no complaints, even though at times he responded to Sulema's requests of material contributions by putting them off to a later occasion.

Reinaldo, on the other hand, was even better positioned to embrace the characteristics associated with responsible masculinity. He was white, in his late forties and employed in a high position that allowed him access to a car and a relatively good salary. Moreover, he received regular remittances from kin in Miami and owned a house equipped with air conditioning and running water. ${ }^{10}$ He charmed Rosa, a 29 -year-old attractive mulata, by showering her with money and gifts, such as a laptop. Reinaldo was successful in his courting: Rosa gave up her job, moved into his house and soon became pregnant with her first child. Reinaldo fitted perfectly with the types of expectations of material resources and responsibility women place on desirable partners and possible father candidates.

However, not all men are capable or willing to fulfil women's expectations of material contributions as successfully. José, a white man in his late thirties, was interested in Flor, another pretty mulata. ${ }^{11}$ Nevertheless, he rejected what he saw as her excessive desire for leisurely outings, stressing that he did not have money for such trivialities as discos, bars and restaurant dinners. However, even in resisting such gendered practices on the use of money, he drew on notions of responsible masculinity to turn down Flor's requests. He emphasised that money must be used on the house, for improving one's home,

10 Reinaldo was in quite a good position in the state hierarchy so in that sense he could perhaps be seen as displaying some of the characteristics of desirable revolutionary masculinity. Nevertheless, his comparatively high income, the fact that he had kin in Miami and such qualities as his lack of athleticism, sharply differentiate him from the exemplary humble, fit, hard-working and committed revolutionary that Che Guevara (2005 [1965]) wrote about in his views on the socialist "new man." 11 The fact that, in all of these cases, my male respondents were trying to court mulatas exemplifies the position of la mulata as the object of desire in Cuba (see Kutzinski 1993). 
on something lasting instead of amusements. This, however, did not land well with Flor, who interpreted his unwillingness to take her out as a lack of interest, and - for worse - started to suspect that he was only looking for ways to move into her house, as she lived alone. Whatever the reason for José's interest in Flor, his tactic of resisting the usual courting practices resulted in his failure to create the relationship he wanted.

Especially when having problems with their partner, several of my male respondents sought to handle the situation by resorting to practices that can be connected to local notions of machismo. ${ }^{12}$ This was particularly likely to take place when men were struggling to fulfil their partner's expectations.

When Armando lost his job, he became unable to continue his contributions to Sulema and her interest started to fade. Armando sought to fix the situation by starting to supervise Sulema's movements, tortured by jealousy for suspecting her to be seeing some other man. One night, he followed Sulema to her home and tried to force his entry into her house. This, however, led to a further cooling down of their relationship and eventually to its ending.

Luis, a mulato man in his early thirties, on the other hand, had all the time kept a strict watch on his partner Rosa. One day he caught her maintaining a friendship with a Canadian man by email. Luis got angry, since for him it was clear that Rosa was planning to migrate out of Cuba by entering into a romantic relationship with the Canadian man. After a while, however, things settled down between Luis and Rosa and the relationship continued. Nevertheless, soon after, Luis caught Rosa in a café with another man, got furious and slapped her. He was hoping this would put her back at bay, but in fact it had the opposite effect, with Luis ending up losing Rosa to another man. The man - indeed - was Reinaldo, who was wealthier and better positioned to fulfil Rosa's aspirations of a more prosperous life. Luis knew he could not compete with the Canadian man for Rosa's affections since he did not have the means to offer her what a foreigner could: migration out of the country. Nor could he compete with what Reinaldo could offer Rosa. Luis had a monthly income of approximately 20 dollars, no car and no house. He was good-looking, well-educated, smart and (most of the time) very good mannered but he lacked money.

The troubles that Luis had in his relationship with Rosa exemplify particularly well the new uncertainties and demands that many men have come to encounter in the post-Soviet period, competing for women's affections with

12 I am aware of the critique (e.g. Gutmann 2005 [1996]) towards the concept of machismo, but Cubans themselves (men, women and the state discourse) use this concept for discussing gender relations (for instance, "Here the men are very machistas"). The term can be used to refer to a number of practices ranging from the gendered aspects of domestic labour to sexual jealousy. The positive and negative aspects of machismo form a continuum that displays some ambiguity and the meanings of the same practice may vary from one situation to another. 
foreigners - advantaged by their offerings of migration - and with the newly wealthy Cubans, who can afford cars, laptops, and air conditioned flats.

Recently, Cubans' relationships with foreigners have received particularly abundant attention from researchers. With the emergence of the mass sex tourism to Cuba during the post-Soviet era, research on sex work in Cuba has shown that many Cubans place expectations of more long-term relationships on the foreigners with whom they enter into contact, blurring the line between ideas of commoditisation and bonds of affect and friendship (Cabezas 2004, 2009; Simoni 2008, 2009, 2012; Alcázar Campos 2009; Fernandez 2010: 130-133; Allen 2011; Roland 2011; Daigle 2013). None of the people with whom I worked was engaged in sex work so my data is limited in this regard. Some women, however, had had relationships with foreign men and the great majority of my female interlocutors expressed desires to find a foreign partner due to the material resources, luxuries and possibilities of migration, travel and leisure that such men were thought to offer. Many of my research participants imagined most foreigners who come to Cuba to be millionaires (how could they otherwise afford to travel so far on a holiday?). At the same time, similar dreams and expectations of social mobility and improved material resources characterised women's expectations of wealthy Cuban men, although in a more moderate form. Those with plenty of material resources are expected to share them with their kin, partners and friends and because foreign men are thought to be considerably richer, the expectations placed on them are greater. ${ }^{13}$

Although most of my male interlocutors situate themselves somewhere in between of extreme forms of wealth and poverty, they all had to come to terms with the type of close intertwining of material resources and attraction that characterises sexual relations in contemporary Havana. In this, they drew on different aspects of local masculinities. Often, a full embracing of the position of a "provider" - showering their partners with gifts and money - helped them to create the relationships that they sought. The situations where they embraced machismo brought them possibly the worst results, with many women rejecting their partner's efforts to control them.

Both of these aspects of masculinity entail their own difficulties. Embracing aspects of responsible masculinity and providing his partner with money and gifts contains the constant possibility that someone may appear offering more, no matter how hard a man tries to provide for his partner. But then again practices that women see as excessive machismo easily lead to the opposite result of that desired by the man - of alienating his partner instead of bringing her closer. Gender relations thus require continuous, often complicated negotiations. Embracing the gendered practices connected to responsible masculinity

13 My female interlocutors also saw foreign men often lacking in such factors of attraction as dancing skills and being a machote. 
in many cases goes hand in hand with machismo. So I do not argue that different men would embrace different notions of masculinities but rather that at distinct moments and situations, men draw on different aspects of the local meanings of how to be a man.

\section{MONETISATION AS TRANSFORMING THE EXPECTATIONS OF GENDERED RECIPROCITY}

As we have seen, the post-Soviet era has seen the emergence of new complexities in love and sexual relations that have the gendered consequence of increasing women's demands of material contributions on men, making access to money and material resources an indispensable part of desirable masculinity.

While both men and women see money as a male form of care and connect it with the way in which a responsible man should behave in a relationship, sometimes men may start to feel more ambiguous about such gendered exchanges.

My male interlocutors sometimes expressed annoyance about the amount of claims that their partners made on them, or complained about how much money they had spent for the benefit of a woman in a relationship. However, this usually took place when a relationship was also flawed by other problems or after a woman had ended the relationship. At the same time, even when expressing such views my respondents never outright denied women's rights to make material claims on them. Rather, they complained about the amount of these claims, that women expect too much. Thus love, care and material contributions intertwine also in men's conceptualisations of romantic relationships, but what becomes the issue is the negotiation of the (imaginary of a) properly balanced reciprocity in a relationship.

Since cultural conceptualisations of a desirable masculinity closely connect men with money and material contributions, for a man to start suggesting that his partner is cultivating a relationship with him primarily for material interests leads to several moral ambiguities.

To propose that his partner is a greedy abusadora who exploits his material contributions raises suspicions of a man's ability to fulfil his position as a real man, one who does not take abuse from anyone. In the light of notions of machismo, this relates to the question of respect in social relations, of whether a person knows how to command respect for himself or instead lets others walk all over him. A person who lets others take advantage of him is not worthy of others' respect since he does not know how to earn respect himself. ${ }^{14}$ Thereby, for a man to imply that a woman is taking advantage of him easily evokes an image that it is his own fault for being such a fool that he lets himself be 
abused by cunning women, leading to a perception of him as weak and lacking masculinity. While men may sometimes complain about women's greediness, at the end it is not in their interest to portray their relationship with women in this way, since this would imply that their relationships are not based on any type of proper reciprocity. This would suggest that they let themselves be used by women, risking to give the appearance of being a "come-mierda" (a shit-eater; a very despising insult).

Moreover, emphasising a man's single-sided material contributions in a relationship may suggest that a man is so unattractive that he may only attract women with money. This would deny any emotional attraction from the woman's part, which again has the potential to question his masculinity, since Cuban conceptualisations of gender involve importantly a notion of mutual heterosexual desirability (see also Lundgren 201 1; Härkönen 2014: 120-161).

Thus, in practice it is often difficult to differentiate between a man's heterosexual desirability and his possessions. While in the beginning of my fieldwork, I kept on pressing my female respondents with questions about whether they liked a man or were mainly interested in what he had to offer, most of the time it was impossible to tease the two apart. This way, having access to material resources gives a man erotic agency, which Holly Wardlow (2006: 232) defines as "the power and delight of being desired."

This close intertwining of material resources and erotic agency is not only connected to transformations and inequalities in sexual relationships between men and women; it also highlights differences between men, in particular when it comes to fatherhood. While some men - like Rosa's white partner Reinaldo - easily attract partners and have several children with various different women (in this case, four children with three different women), others such as my very poor, black, artist friend Osmael - risk remaining childless, as they struggle to find a woman who would be willing to maintain a relationship with a man who is constantly broke, let alone to have a child with such a partner. With white or lighter-skinned men more likely to have an advantageous access to money and other forms of material resources (see de la Fuente 2001 a, 200lb; Allen 2011: 119-120), such views about desirable masculinity carry the potential to make the inequalities of the post-Soviet period particularly poignant, emphasising their racialised and gendered characteristics.

This way, Cuba's new economy puts some men in a particular risk of remaining childless, a great tragedy because parenthood is of crucial significance to the normal life course and full adulthood for both men and women. Moreover, remaining childless is not just an emotional tragedy, it risks marginalising a person more thoroughly (if there is no further family around), because in contemporary Cuba, the nurturing support provided by an individual's family relations plays a central role in surviving the pragmatics of everyday life (see also Andaya 2007). 
Moreover, the fact that such practices and views about desirable masculinity and ideal fatherhood easily evoke colonial-era memories (see Martinez-Alier 1974) of wealthy white men entering into relationships with beautiful mulatas - often in highly unequal conditions - fits uneasily with larger discourses of the socialist nation, claiming to make a clear break with its colonial past. If racialised inequalities of wealth become materialised at grassroots-level intimate attachments and reproductive practices as my material suggests, this strikes at the heart of state egalitarianism, when poverty becomes a significant factor inhibiting individuals from creating relationships and seeking continuity for their lives through children. Inequality is not just a question of economic marginalisation, but comes to threaten a man's whole social being.

\section{CONCLUSION}

The transformations of Cuban society in the post-Soviet era have had importantly gendered consequences, transforming differently the lives of men and women. In their ways to deal with such large-scale changes as monetisation and declining state subsidies, men and women draw on local gendered practices and meanings. For women in particular, love and sexual relations are an important way to generate income and gain social mobility; simultaneously, they continue to maintain greater responsibility for dependent family members than men. In making their demands on men, women can draw on longer-standing conceptualisations of masculinity. Many men, on the other hand, struggle with women's expectations of material resources, gifts and lucrative consumption. Currently getting by economically is highly difficult for many Cubans, at the same time as the island has become flooded with new desires and dreams of a better life.

My ethnographic evidence shows that men cope with women's intensified demands by embracing distinct aspects of cultural conceptualisations of how to be a man, drawing at times on notions of responsible masculinity, at times on machismo. The increased importance of material resources to men's ability to create relationships, however, puts some men at a considerable disadvantage. Because money has become to significantly represent something that allows a man to create relationships, the men who are unable or unwilling to make material contributions to women may struggle to establish relations. At worst, this may mean that they remain childless, as women lay particular emphasis on the material resources of potential father candidates, being highly committed to provide for their child as favourable material conditions as possible. Cuba's large-scale transformations in the post-Soviet era not only have gendered consequences, but they also highlight differences and inequalities between men, as money, material resources and attractiveness intertwine and connect with gendered meanings and practices in contemporary intimate relationships. 


\section{REFERENCES}

ALCÁZAR CAMPOS, Ana, 2009, "Turismo sexual, jineterismo, turismo de romance: fronteras difusas en la interacción con el otro en Cuba", Gazeta de Antropología, 25 (1): \# 16.

ALLEN, Jafari Sinclaire, 2011 , iVenceremos?: The Erotics of Black Self-Making in Cuba. Durham, Duke University Press.

ANDAYA, Elise, 2007, Reproducing the Revolution: Gender, Kinship and State in Contemporary Cuba. New York, New York University, PhD dissertation.

ANDAYA, Elise, 2009a, "The gift of health: Cuban medical practice, socialist morality, and the post-Soviet economy”, Medical Anthropology Quarterly, 23 (4): 357-374.

ANDAYA, Elise, 2009b, "Engendering the future", paper presented at "LASA 2009: Rethinking Inequalities", Latin American Studies Association, Rio de Janeiro, June.

ANONYMOUS, 2008, "Cuba to abandon salary equality", BBC News, 12 June, < http://news. bbc.co.uk/2/hi/7449776.stm > (last access May 2015).

AZICRI, Max, 2000, Cuba Today and Tomorrow: Reinventing Socialism. Miami, University Press of Florida.

BARrow, Christine (ed.), 1996, Family in the Caribbean: Themes and Perspectives. Kingston, Ian Randle Publishers.

BROTHERTON, Sean Pierre, 2005, "Macroeconomic change and the biopolitics of health in Cuba's special period”, Journal of Latin American Anthropology, 10 (2): 339-369.

BROTHERTON, Sean P., 2008, “'We have to think like capitalists but continue being socialists': medicalized subjectivities, emergent capital, and socialist entrepreneurs in postSoviet Cuba", American Ethnologist, 35 (2): 259-274.

BUTTERWORTH, Douglas, 1980, The People of Buena Ventura: Relocation of Slum Dwellers in Post-Revolutionary Cuba. Urbana, University of Illinois Press.

CABEZAS, Amalia, 2004, "Between love and money: sex, tourism, and citizenship in Cuba and the Dominican Republic", Signs: Journal of Women in Culture and Society, 29 (4): 987 1015.

CABeZAS, Amalia L., 2009, Economies of Desire: Sex and Tourism in Cuba and the Dominican Republic. Philadelphia, Temple University Press.

CLARKE, Edith, 1974 [1957], My Mother Who Fathered Me: A Study of the Family in Three Selected Communities in Jamaica. London, Allen \& Unwin.

COLE, Jennifer, 2009, "Love, money, and economies of intimacy in Tamatave, Madagascar", in Jennifer and Lynn M. Thomas (eds.), Love in Africa. Chicago, The University of Chicago Press, 109-134.

COLE, Jennifer, and Lynn M. THOMAS, 2009, "Introduction", in Jennifer Cole and Lynn M. Thomas (eds.), Love in Africa. Chicago, The University of Chicago Press, 1-30.

DAIGLE, Megan, 2013, "Love, sex, money and meaning: using language to create identities and challenge categories in Cuba”, Alternatives: Global, Local, Political, 38 (1): 63-77.

DE LA FUENTE, Alejandro, 2001a, "Recreating racism: race and discrimination in Cuba's 'Special Period”, Socialism and Democracy, 15 (1): 65-91.

DE LA FUENTE, Alejandro, 200lb, "The resurgence of racism in Cuba", NACLA Report on the Americas, 34 (6): 29-34.

DÍAZ TENORIO, Maréleen, 1993, Uniones Consensuales de Cuba. Havana, Departamento de Estudios sobre Familia, Centro de Investigaciones Psicológicas y Sociológicas, Ministerio de la Ciencia, Tecnología y Medio Ambiente. 
ECKSTEIN, Susan Eva, 1994, Back from the Future: Cuba under Castro. Princeton, Princeton University Press.

ENGELS, Friedrich 2004 [1884], The Origin of the Family, Private Property and the State: in the Light of Researches of Lewis H. Morgan. Newtown, Resistance Books.

FERNANDEZ, Nadine, 2010, Revolutionizing Romance: Interracial Couples in Contemporary Cuba. New Brunswick, Rutgers University Press.

FreEMAN, Carla, 2000, High Tech and High Heels in the Global Economy: Women, Work, and Pink Collar Identities in the Caribbean. Durham, Duke University Press.

FREEMAN, Carla, 2001, "Is local:global as feminine:masculine? Rethinking the gender of globalization”, Signs, 26 (4): 1007-1037.

GAL, Susan, and Gail KLIGMAN, 2000a, Reproducing Gender: Politics, Publics and Everyday Life after Socialism. Princeton, Princeton University Press.

GAL, Susan, and Gail KLIGMAN, 2000b, The Politics of Gender after Socialism: A Comparative-Historical Essay. Princeton, Princeton University Press.

GODELIER, Maurice, 1999, The Enigma of the Gift. Chicago, The University of Chicago Press. GUEVARA, Ernesto Che, 2005 [1965], El Socialismo y el Hombre en Cuba. Melbourne, Ocean Press.

GUSSLER, Judith D., 1996 [1980], "Adaptive strategies and social networks of women in St. Kitts", in Christine Barrow (ed.), Family in the Caribbean: Themes and Perspectives. Kingston, Ian Randle Publishers, 119-135.

GUTMANN, Matthew C., 1997, "The ethnographic (g)ambit: women and the negotiation of masculinity in Mexico City”, American Ethnologist, 24 (4): 833-855.

GUTMAnN, Matthew C., 2007 [1996], The Meanings of Macho: Being a Man in Mexico City. Berkeley, University of California Press.

Hamilton, Carrie, 2012, Sexual Revolutions in Cuba: Passion, Politics and Memory. Chapel Hill, University of North Carolina Press.

HÄrKÖNEN, Heidi, 2014, "To Not Die Alone": Kinship, Love and Life Cycle in Contemporary Havana, Cuba. Helsinki, Unigrafia.

HIRSCH, Jennifer S., and Holly WARDLOW (eds.), 2006, Modern Loves: The Anthropology of Romantic Courtship and Companionate Marriage. Ann Arbor, University of Michigan Press.

HOLBRAAD, Martin, 2004, “Religious 'speculation': the rise of Ifá cults and consumption in Post-Soviet Cuba”, Journal of Latin American Studies, 36: 643-663.

HUNTER, Mark, 2009, "Providing love: sex and exchange in twentieth-century South Africa”, in Jennifer Cole and Lynn M. Thomas (eds.), Love in Africa. Chicago, The University of Chicago Press, 135-156.

KATH, Elizabeth, 2010, Social Relations and the Cuban Health Miracle. New Brunswick, Transaction Publishers.

KUTZINSKI, Vera M., 1993, Sugar's Secrets: Race and the Erotics of Cuban Nationalism. Charlottesville and London, University Press of Virginia.

LUNDGREN, Silje, 201 1, Heterosexual Havana: Ideals and Hierarchies of Gender and Sexuality in Contemporary Cuba. Uppsala, Uppsala University, PhD dissertation in Cultural Anthropology.

MARTINEZ-ALIER, Verena, 1974, Marriage, Class and Colour in Nineteenth Century Cuba: a Study of Racial Attitudes and Sexual Values in a Slave Society. Cambridge and London, Cambridge University Press. 
NEWMAN, Brooke N., 2010, "Gender, sexuality and the formation of racial identities in the eighteenth-century Anglo-Caribbean world", Gender and History, 22 (3): 585-602. ONEC (Oficina Nacional de Estadísticas de Cuba), 2010, "Empleo en cifras: Cuba 2010", available at < http://www.one.cu/publicaciones/03estadisticassociales/Empleo\%20 en\%20Cifras\%20Cuba\%202010/poblacioneconomicamenteactiva.pdf > (last access 7/1/2013).

PERTIERRA, Anna, 2008, "En casa: women and households in post-Soviet Cuba", Journal of Latin American Studies, 40: 743-767.

PORTER, Amy L., 2008, "Fleeting dreams and flowing goods: citizenship and consumption in Havana, Cuba", PoLAR: Political and Legal Anthropology Review, 31 (1): 134-149.

ROLAND, Kaifa L., 2006, "Tourism and the negrificación of Cuban identity", Transforming Anthropology, 14 (2): 151-162.

ROLAND, Kaifa L., 2011 , Cuban Color in Tourism and La Lucha: An Ethnography of Racial Meanings. New York, Oxford University Press.

ROSENDAHL, Mona, 1997, Inside the Revolution: Everyday Life in Socialist Cuba. Ithaca, Cornell University Press.

SAFA, Helen, 2005, "The matrifocal family and patriarchal ideology in Cuba and the Caribbean", Journal of Latin American Anthropology, 10 (2): 314-338.

SIMONI, Valerio, 2008, "Shifting power: the (de)stablization of asymmetries in the realm of tourism in Cuba", Tsantsa, 13: 89-97.

SIMONI, Valerio, 2009, "Scaling cigars in the Cuban tourism economy", Etnográfica, 13 (2): 417-438.

SIMONI, Valerio, 2012, "Dancing tourists: tourism, party and seduction in Cuba", in David Picard and Mike Robinson (eds.), Emotion in Motion: Tourism, Affect and Transformation. Farnsham, Ashgate, 267-281.

SMITH, Raymond T., 1988, Kinship and Class in the West Indies: A Genealogical Study of Jamaica and Guyana. Cambridge, Cambridge University Press.

SMITH, Raymond T., 1996: The Matrifocal Family: Power, Pluralism and Politics. New York, Routledge.

STRATHERN, Marilyn, 1988, Gender of the Gift: Problems with Women and Problems with Society in Melanesia. Berkeley, University of California Press.

STUBBS, Jean, 1997, review of Helen I. Safa, The Myth of the Male Breadwinner: Women and Industrialization in the Caribbean, Journal of Latin American Studies, 29 (1): 254-255.

VERDERY, Katherine, 1996, What Was Socialism and What Comes Next? Princeton, Princeton University Press.

WARDLOW, Holly, 2006, Wayward Women: Sexuality and Agency in a New Guinea Society. Berkeley, University of California Press.

WEINREB, Amalia Rosenberg, 2008, "Race, fé (faith) and Cuba's future”, Transforming Anthropology, 16 (2): 168-172.

WILSON, Peter, 1973, Crab Antics: The Social Anthropology of English-Speaking Negro Societies of the Caribbean. New Haven, Yale University Press.

WONG, David C., 1996, "A theory of petty trading: the Jamaican higgler", The Economic Journal, 106 (435): 507-518. 